\title{
Subject Matter Specialization of European Union Jurisdiction in the Preliminary Rulings Procedure
}

\author{
Matthias Jacobs ${ }^{\star}$, Matthias Münder ${ }^{\star *}$ (i) and Barbara Richter ${ }^{\star * * * * * *}$
}

(Received 29 October 2018; accepted 06 December 2018)

\begin{abstract}
Over the years, judgments by the European Court of Justice ("ECJ") have been-sometimes heavilycriticized. While the recent reforms to the EU's judicial system have addressed the high caseload of the General Court of the European Union ("GC"), the perceived lack of quality of the ECJ's judgments in preliminary rulings procedures remains an issue. This Article will outline in what way these judgments are criticized and try to examine the root causes of the criticism. It goes on to argue that subject matter specialization is an adequate answer to this criticism and examines how subject matter specialization can be introduced into the European Union ("EU") judicial system.
\end{abstract}

Keywords: European Union jurisdiction; specialization; preliminary rulings procedure; specialized chambers; third party intervention

\section{A. Current Reforms in the Jurisdiction of the European Union}

The Court of Justice of the European Union (“CJEU”), in particular its Court of Justice (“ECJ”), has repeatedly been described as a "motor of integration." Its authority lets EU law become social reality. Because the EU lacks a coercive power to enforce its law, it relies on its member states accepting EU law and implementing it according to the mold provided by the EU's judiciary. If European integration is the aim, it must be a priority to further raise the level of acceptance of the EU's jurisdiction. That in turn requires a periodic reassessment of the constitution of the CJEU for potential improvements. Current reforms demonstrate that the reassessment has not been neglected.

Effective September 1, 2016, the European Union Civil Service Tribunal ("Civil Service Tribunal") was integrated into the GC. ${ }^{2}$ As this restructuring unfolded, the number of judges

${ }^{\star}$ Matthias Jacobs is Professor of Law, Chair of Private Law, Employment Law and Civil Procedure at Bucerius Law School, Hamburg, Germany.

${ }^{* *}$ Matthias Münder is a research assistant to Professor Jacobs.

${ }^{* * *}$ Barbara Richter is a research assistant to Professor Jacobs.

${ }^{* * * *}$ This Article is based on research for the Hugo Sinzheimer Institut in German in Jacobs/Münder/Richter, Spezialisierung der Unionsgerichtsbarkeit im Arbeitsrecht - Fachkammer für Arbeitsrecht am EuGH (2016), HSI-Schriftenreihe Vol. 17 (available at https://www.hugo-sinzheimer-institut.de/fileadmin/user_data_hsi/Veroeffentlichungen/HSI_Schriftenreihe/ Jacobs_Spezialisierung_der_Unionsgerichtsbarkeit.pdf). This Article was translated by John Augustus Foulks, Esq.

${ }^{1}$ Torsten Stein, Richterrecht wie anderswo auch?, in RICHTERLICHE RECHTSFORTBILDUNG: ERSCHEINUNGSFORMEN, AUFTRAG UND GRENZEN 619 (1986); see also P. Kirchhof, $\$ 214$ Der deutsche Staat im Prozeß der europäischen Integration, in Handbuch des StaAtsrechts Band IX, 61, 153 (J. Isensee \& P. Kirchhof eds., 3rd ed. 2012); Thomas Horsley, Reflections on the Role of the Court of Justice as the "Motor" of European Integration: Legal Limits to Judicial Lawmaking, 50 Common MKT. L. Rev. 931 (2013).

(C) The Author(s) 2019. Published by Cambridge University Press on behalf of the German Law Journal. This is an Open Access article, distributed under the terms of the Creative Commons Attribution-NonCommercial-NoDerivatives licence (http://creativecommons.org/licenses/ by-nc-nd/4.0/), which permits non-commercial re-use, distribution, and reproduction in any medium, provided the original work is unaltered and is properly cited. The written permission of Cambridge University Press must be obtained for commercial re-use or in order to create a derivative work. 
serving on the GC eventually doubled as a result of three discrete increases. From September 1, 2019, onward, it is composed of two judges for each Member State. ${ }^{3}$ The increase in the number of judges is meant to enable cases to be heard within a reasonable time as mandated by Article 47 of the Charter of Fundamental Rights of the European Union. ${ }^{4}$ In Article 3 (2) of Regulation 2015/ 2422, the Council and Parliament tasked the ECJ with drawing up a report by December 26, 2017, on possible changes to the distribution of competence for preliminary rulings. In its report, the ECJ weighs the advantages and disadvantages of allocating to the GC some references for a preliminary ruling ${ }^{5}$ and advocates against changing the distribution of jurisdiction over preliminary rulings. ${ }^{6}$ This Article outlines a range of possible changes to the preliminary rulings procedure and advocates for reform while maintaining the current distribution of jurisdiction over preliminary rulings as suggested by the ECJ.

First, we deal with some criticisms of ECJ judgments in the preliminary rulings procedure and examine their root causes. Such criticism can hurt acceptance of the ECJ because the preliminary rulings procedure, which is a nexus between national and European law, represents a departure from the national legal orders. The judiciary can gain acceptance-so this Article claims-by introducing into the preliminary rulings procedure a specialization of EU jurisdiction by subject matter. Following this, in the second part of the Article we deal with various models of reform geared toward a specialized preliminary rulings procedure. We conclude with a number of minor proposals toward developing the jurisdiction of the EU.

\section{B. Criticism of Judgments of the ECJ, Its Causes, and Effects}

Overall, the ECJ has mastered with bravura its task of interpreting EU law such that it is applied evenly in all Member States. This is particularly so in light of numerous hurdles the judges in Luxemburg have to overcome. ${ }^{7}$ Despite this astounding success story, the decisions of the ECJ are often criticized. As part of the study underlying this Article, we examined the judgments in Viking, ${ }^{8}$ Laval, ${ }^{9}$ and Alemo-Herron ${ }^{10}$ as examples of the ECJ's criticized decisions in employment law which have come down through the preliminary rulings procedure. Surely, however, the points of criticism will be found to echo through reactions to ECJ decisions in other areas of law.

\section{Criticism}

1. Inconsistent Decisions and Flawed Systematization

The ECJ gets accused of deciding matters case by case and paying little attention to systematic development. The decisions_-so the criticism goes_-are sometimes contradictory, or at least

\footnotetext{
${ }^{2}$ See Commission Regulation 2016/1192, 2016 O.J. (L 200) 137. See also Alberto Alemanno \& Laurent Pech, Thinking Justice Outside the Docket: A Critical Assessment of the Reform of the EU's Court System, 54 Common MKT. L. REv. 129 (2017) (giving a detailed report and analysis of the reform process).

${ }^{3}$ See Romain Rousselot, Tribunal: Une Réforme du Statut de la Cour de Justice de l'Union Européenne en Demi-Teinte, 1 Eur. PAPERS 275, 280-82 (2016) (presentation of the reform of the ECJ).

${ }^{4}$ Cf. Commission Regulation 2015/2422, 2015 O.J. (L 341) 14.

${ }^{5}$ See Council of THE EUR. UnION, Report of the Court of Justice on Possible Changes to the Distribution of Competence for Preliminary Rulings Under Article 267 TFEU, 15995/17 (2017), at 5. http://data.consilium.europa.eu/doc/document/ST15995-2017-INIT/en/pdf.

${ }^{6} \mathrm{See}$ id. at 8.

${ }^{7}$ On this, see the basis for criticism infra Section III.

${ }^{8}$ See generally Case C-438/05, International Transp. Worker's Fed'n v. Viking Line, 2007 E.C.R. I-10779.

${ }^{9}$ See generally Case C-341/05, Laval un Partneri Ltd. v. Svenska Byggnadsarbetareförbundet, 2007 E.C.R. I-11767.

${ }^{10}$ See generally Case C-426/11, Mark Alemo-Herron v. Parkwood Leisure Ltd., 2013 E.C.R.
} 
not consistent with one another. ${ }^{11}$ A few judgments are not even consistent internally, ${ }^{12}$ while others do not allow an unambiguous rule to be discerned. ${ }^{13}$ In the area of employment law, typical examples are decisions such as those pertaining to the Transfers of Undertakings Directive, ${ }^{14}$ the Working Time Directive, ${ }^{15}$ and the Posting of Workers Directive. ${ }^{16}$ A major obstacle for anyone applying the law here is that the ECJ does not clarify when it departs from, or corrects, an earlier precedent. $^{17}$

\section{Insufficient Setting Forth of Reasons and Deficient Portrayal of a System}

Aside from the flawed development of any system, probably the greatest point of criticism is that the ECJ often just does not set forth sufficient reasoning in its decisions. ${ }^{18}$ The more important a statement, the more detailed its underlying reasoning ought to be. Yet, in the ECJ's decisions oftentimes the reverse is true, ${ }^{19}$ especially where fundamental doctrinal principles are concerned, and despite the fact that these are the starting point for systematization of a given area of law. ${ }^{20}$

\footnotetext{
${ }^{11}$ See generally J. Heuschmid, Anmerkung zu EuGH 18.07.2013 C-426/11 (Alemo-Herron u. a./Parkwood Leisure Ltd), 61 ARbeIT UND ReCHT (2013); cf. L. Woods, Consistency in the Chambers of the ECJ: A Case Study on the Free Movement of Goods, 31 Civ. Just. Q. 339, 350-67 (2012) (finding the ECJ's approach to Articles 34-36 TFEU to be inconsistent).

${ }^{12}$ E.g., Case C-438/05, supra note 8 (a main example from legal literature); see also Case C-341/05, supra note 9 (same); Robert Rebhahn, Die Aktuelle Rechtsprechung des EuGH vor dem Hintergrund des Verhältnisses von Grundfreiheiten und Gemeinschaftsgrundrechten, in DIE AUSWIRKUNGEN DER RECHTSPRECHUNG DES EUROPÄISCHEN GERICHTSHOFS AUF DAS Arbeitsrecht Der MitgliedstaAten 17, 18 (O. Scholz \& U. Becker eds., 1st ed. 2009); cf. e.g., F. Bayreuther, Das Verhältnis Zwischen dem Nationalen Streikrecht und der EU, Wirtschaftsverfassung, 2008 EUROPÄISCHE ZEITSCHRIFT FÜR ARBEITSRECHT 395, 401.

${ }^{13}$ See Karl-Georg Loritz, Anmerkung zu EuGH 14.4.1994 - C-392/92 (Christel Schmidt), ARbEITSRECHTLICHE PRAXIS 106-\$ 613a; see also B. Schiefer, Anmerkung zu LAG Düsseldorf 9.11.1994 - 2 Sa 525/94, 1995 Der Betrieb 276, 277.

${ }^{14}$ See generally Case C-392/92, Christel Schmidt v. Spar- und Leihkasse der fruheren Amter Bordesholm, 1994 E.C.R. I01311; Case C-446/07, Alberto Severi v. Regione Emilia Romagna, 2009 E.C.R. I-08041; Case C-108/10, Ivana Scattolon v. Ministero dell'Istruzione, 2011 E.C.R. I-07491; Case C-328/13, Österreichischer Gewerkschaftsbund v. Wirtschaftskammer Osterreich, 2014 E.C.R.

${ }^{15}$ See generally Joined Cases C-350 \& 520/06, Gerhard Schultz-Hoff v. Deutsche Rentenversicherung Bund, Stringer and Others v. Her Majesty's Revenue and Customs, 2009 E.C.R. I-00179.

${ }^{16}$ See generally Case C-346/06, Dirk Rüffert v. Land Niedersachsen, 2008 E.C.R. I-01989.

${ }^{17}$ See Matthias Jacobs et al., Spezialisierung der Unionsgerichtsbarkeit im Arbeitsrecht?, 65 ARBEIT UND RECHT 210, 211 (2017); cf. Wulf-Henning Roth \& Christian Jopen, \$ 13 Die richtlinienkonforme Auslegung, in EUROPÄISCHE Methodenlehre: Handbuch für Ausbildung und Praxis 29 (K. Riesenhuber ed., 3rd ed. 2015) (arguing it is unclear whether, with its judgment in Adeneler, the ECJ has abandoned its line of decisions in Wagner Miret, Pfeiffer and Björnekulla Fruktindustrier on the national legislature's preparedness to implement and the lessened significance of legislative materials in interpretation).

${ }^{18}$ See Franklin Dehousse, The Reform of the EU Courts (IV). The Need for a Better Focus on the European Court of Justice's Core Mission, Egmont Paper 96, Sept. 2017, http://aei.pitt.edu/89841/1/egmont.papers.96_v1.pdf (showing that even sceptics of specialization agree); see also Jacobs, supra note 17, at 211; Eleanor Sharpston, Making the Court of Justice of the European Union More Productive, 21 MAASTRICHT J. Eur. \& COMP. L. 763, 765 (2014) (where the Advocate General of the ECJ states that there are judgments "with gaps in the reasoning" or "with bland opacity in key passages"); Norbert Reich, Free Movement v. Social Rights in an Enlarged Union - the Laval and Viking Cases before the ECJ, 9 GERMAN L.J. 125, 159 (2008).

${ }^{19}$ See generally Case C-438/05, supra note 8 (there is no sufficient statement of reason for the applicability of the fundamental freedoms to industrial actions. Furthermore, the validity of the so-called "theory of third-party effect of fundamental rights" depends on this reasoning); Case C-426/11, supra note 10 (the ECJ refers neither to the contractual freedom of employees nor explains the prevailing of the acquirer's rights); cf. EUR. PARL. DOC. (2008/2085(INI)) (2008), http://www.europarl. europa.eu/RegData/seance_pleniere/textes_adoptes/definitif/2008/10-22/0513/P6_TA(2008)0513_EN.doc (outlining challenges to collective agreements in the EU); Loic Azoulai, Le Role Constitutionnel de la Cour de Justice des Communautés Européennes tel qu'il se degage de sa Jurisprudence, 44 REvue TrIMESTRIELLE DE DROIT EUROPEEN 29, 32 (2008); see also Sylvaine Laulom, Les Arrêts Viking et Laval: et Après?, 748 LE DroIT OuvrIER 570, 571 (2010); Robert Rebhahn, Grundfreiheit vor Arbeitskampf - der Fall Viking, 3 ZEITSCHRIFT FÜR EUROPÄISCHES SOZIAL-UND ARBEITSRECHT (ZESAR) 109, 113 (2008); Gerrit Forst, Betriebsübergang: Ende der Dynamik einer arbeitsvertraglichen Bezugnahme auf einen Tarifvertrag?, 2013 DER BETRIEB 1847, 1850.

${ }^{20} \mathrm{Cf}$. Bayreuther, supra note 12, at 398; see also Rebhahn, supra note 19 , at 112 .
} 
Sometimes the ECJ does not address the questions put to it although they touch central issues. ${ }^{21}$ When it departs from the wording of a provision, the ECJ's reasoning is often quite brief. This makes it difficult to understand the consequences of the decision.

In its opinions, the ECJ commonly uses the technique of referencing its earlier decisions. But at the same time it only rarely provides reasons why the factual circumstances underlying the judgments are at all comparable to one another. ${ }^{22}$ Without this reasoning, one can only conjecture about the basis for comparison. As a result, many judgments are not easy to grasp and are difficult to analyze critically.

\section{Poor Understanding of Factual and Legal Circumstances}

Some decisions create the impression that a better grasp of the factual, and even the legal circumstances might have led to better, more widely accepted judgments. In particular, there have been calls for better awareness of the national legal orders. ${ }^{23}$ A certain superficiality is on display, for example, where a judgment does not precisely set forth the legal foundation. In one such case, Alemo-Herron, the ECJ did not clearly distinguish between rights under employment contracts versus under collective bargaining agreements. The judgments in Laval and Viking have occasioned the statement that the ECJ has a "poor understanding of the industrial relations background". ${ }^{24}$ Here too, a more intensive analysis of the substance would presumably have led to a better result.

\section{Insufficient Sensitivity to the Consequences}

The desire for better understanding of the national legal regimes goes beyond the referring Member State and calls for greater sensitivity to the effect a judgment will have on legal systems throughout the Member States. When the ECJ, in making its determination, directs its attention only to the Member State where the referral originated, overly inclusive statements have the potential to endanger well-balanced systems of law, and to shift existing balances to the prejudice of one interest or another. ${ }^{25}$

\section{Effects of the Criticized Decisions}

\section{Diminished Acceptance and Lack of Legal Certainty}

Judgments that barely set forth reasons, or do so incomprehensibly, do not really gain acceptance in the Member States and are therefore only reluctantly complied with. The inability to discern an unambiguous line in the decisions moreover leads to legal uncertainty. ${ }^{26}$ After Viking and Laval, for instance, numerous authors read the manner in which those opinions addressed, or omitted to

\footnotetext{
${ }^{21}$ See Jacobs, supra note 17 , at 211.

${ }^{22}$ See Loritz, supra note 13.

${ }^{23}$ E.g., Jobst-Hubertus Bauer \& Christian Arnold, EuGH kippt deutsches Urlaubsrecht: Die Schultz-Hoff-Entscheidung und ihre Folgen, 2009 NeUE JuRISTISCHE WOCHENSCHRIFT 631, 632.

${ }^{24}$ A.C.L. Davies, One Step Forward, Two Steps Back? The Viking and Laval Cases in the ECJ, 37 InDUs. L.J. 126, 126, 144-45, 148 (2008); see also Laulom, supra note 19, at 571.

${ }^{25}$ See Schiefer, supra note 13, at 277; see also Marcus Bieder, Die Bewahrung der organisatorischen Selbständigkeit der übertragenen Einheit - konstitutive Voraussetzung eines Betriebsübergangs?, 2009 EUROPÄISCHE ZEITSCHRIFT FUR ARbeITSRECHT 513, 519; H. J. Willemsen, Erneute Wende im Recht des Betriebsübergangs - ein "Christel Schmidt II"Urteil des EuGH?, 2009 Neue ZeitsChrift Fur ARBeitsRecht 289, 293. See generally M. Schlachter, Betriebsübergang bei "eigenwirtschaftlicher Nutzung" von Betriebsmitteln des Auftraggebers, 2006 NeUE ZEITSCHRIFT FUR ARBEITSRECHT 80; Gerrit Forst, Anmerkung zu EuGH, 11.09.2014 - C-328/13: Arbeitsrecht: Nachwirkung von Kollektivverträgen bei Betriebsübergang, 2014 EUROPÄISCHE ZeITSCHRIFT FÜR WIRTSCHAFTSRECHT 822.

${ }^{26}$ See Forst, supra note 25, at 822; see also Ariane Wiedmann, Anmerkung zu EuGH, 3.4.2008 - C-346/06: Vergabe von öffentlichen Bauaufträgen nur an tariflohnzahlende Unternehmen verstößt gegen Richtlinie 96/71/EG - Dirk Rüffert/Land Niedersachsen, 2008 EUROPÄISCHE ZEITSCHRIFT FÜR WIRTSCHAFTSRECHT 308, 310.
} 
address, the European fundamental rights as a signal that ECJ assumed the fundamental freedoms take precedence over the European fundamental rights. ${ }^{27}$ Even if former ECJ President Vassilios Skouris has roundly rejected such an interpretation, ${ }^{28}$ where judgments are short on reasoning, anyone applying the law remains uncertain what the law is.

Should the ECJ wish to make an even greater contribution to a European legal culture, it must comprehensibly set forth "all reasons for and against." ${ }^{\text {" } 9}$ The brief presentation of reasons makes it burdensome to critically analyze the substance of decisions. Though that is precisely what must be possible when it comes to putting anyone in a position to advocate for acceptance of the ECJ's decisions. $^{30}$

\section{Negative Impact on the Referral Practice of National Courts}

The lack of legal certainty that follows from insufficiently reasoned opinions and poor awareness of the consequences of decisions affects the referral practice of national courts. ${ }^{31}$ Although the practice incurs criticism, national courts sometimes do not refer matters for preliminary ruling in order to protect the national legal system from unpredictable consequences, complicating the ECJ's task of safeguarding the coherence of EU law. Conversely, national courts will also refer already settled issues, hoping the ECJ will reconsider its previous decisions. ${ }^{32}$ Furthermore, lack of systematic development means the ECJ finds itself presented with legal questions that do not deviate essentially from questions decided in earlier cases, which unnecessarily increases its workload.

\section{Causes of the Criticism and Specialization as a Possible Solution}

What challenges do the judges on the ECJ face? What circumstances complicate adjudication at the ECJ? Can they be alleviated by specialization?

\section{No Case Overload}

Because the EU has expanded and its competences have grown, it seems reasonable to assume that the judges on the ECJ are burdened by an increasing number of cases, the sheer quantity of which is hard for them to handle. ${ }^{33}$

Yet, it turns out that the risk of overload from the number of cases is small. Each expansion of the EU has been attended by new judgeships at the ECJ such that the number of personnel has grown in kind. Moreover, a careful look at the 2015 report on judicial activity shows that the number of new cases in recent years has stabilized between 622 and 713. ${ }^{34}$ Thus, in absolute terms

\footnotetext{
${ }^{27}$ See Davies, supra note 24, at 147; see also Rebhahn, supra note 18, at 114-15.

${ }^{28}$ See V. Skouris, Das Verhältnis der Grundfreiheiten zu den Gemeinschaftsgrundrechten, 2009 RECHT DER ARBEIT 25, 28; see also V. Skouris, Das Verhältnis von Grundfreiheiten und Grundrechten im europäischen Gemeinschaftsrecht, 2006 DIE ÖFFENTLICHE VERWALTUNG 89, 95-96.

${ }^{29}$ Rebhahn, supra note 19 , at 110.

${ }^{30}$ See Rebhahn, supra note 19 , at 110 .

${ }^{31}$ See Sharpston, supra note 18, at 766; see also Dehousse, supra note 18, at 23.

${ }^{32}$ See Sharpston, supra note 18 , at 766.

${ }^{33}$ See Ulrich Everling, Referat, in Ständige Deputation des Deutschen JuRistentages, VerhandLUNGEN DES 60. DEUTSCHEN JURISTENTAGES, N 9 at N 10 (1994); see also Waltraud Hakenberg, Vorschläge zur Reform des Europäischen Gerichtssystems, 2000 ZEITSCHRIFT FUR EUROPAISCHES PRIVATRECHT 860, 860-61; Franklin Dehousse, The Reform of the EU Courts (II): Abandoning the Management Approach by Doubling the General Court, Egmont Paper 83, at 73-74, 7781 (Mar. 2016), http://www.egmontinstitute.be/content/uploads/2016/03/ep83.pdf.pdf?type=pdf (providing a summary presentation of statistics on pending cases and the duration of proceedings. See generally Anthony Arnull, Refurbishing the Judicial Architecture of the European Community, 43 INT'L CoMP. L. Q. 296 (1994).

${ }^{34}$ See generally Court of Justice of the European Union, Annual Report 2015-Judicial Activity, https://curia.europa.eu/ jcms/upload/docs/application/pdf/2016-08/rapport_annuel_2015_activite_judiciaire_en_web.pdf.
} 
the number of cases per judge lies below that of high court justices in the Member States. ${ }^{35} \mathrm{Up}$ through 2014, one can even observe an increase in the number of disposed cases as well as shorter disposition times. According to former ECJ President Vassilios Skouris, the improvement is due to more efficient working methods and new procedural avenues to accelerate litigation. ${ }^{36}$ Also, one possible explanation - though a mere suspicion—-may be that there were no essential personnel changes at the ECJ in 2014.

Consequently, the difficulties of the EU's jurisprudence are not rooted in case load or the capacities of the judges, nor will possible solutions originate there. Solutions therefore must be sought in the substantial challenges of the proceedings themselves.

\section{Adjudication in a Multi-Level System}

The preliminary rulings procedure is meant to ensure that EU law is applied evenly. The task is a difficult one as the character of EU law is merely fragmentary, meant to protect national legal orders and the sovereignty of Member States. Accordingly, EU law and Member State national law are complementary.

The ECJ's decisions under the preliminary rulings procedure are binding interpretations of the Treaties, Article 267 (1)(a) TFEU. Because Member State courts are the actors who refer questions for preliminary ruling, the procedures are always embedded in a national context. For any given ruling, it would be possible to evaluate and decide in light of how it will affect other Member States, but this is seldom done. As currently organized, the ECJ is unable to foresee the effects of its rulings. The judges are highly qualified jurists who have distinguished themselves first within their own legal systems, and they possess excellent knowledge of European and international law. However, it is virtually impossible to require that they should know about the other Member States' legal orders, and the resources are simply not available by which to compensate for this knowledge deficit. To be sure, it is also incumbent upon the governments to brief the Court on foreseeable effects of a preliminary ruling beyond the referring state. ${ }^{37}$

Without a doubt, foreseeing such effects is an enormous task. But then again it can have an undesirable effect on otherwise well-balanced systems in the Member States if effects of a judgment are not properly foreseen. It might, for example, lead to overregulation if functionally equivalent protections in Member State law are not accounted for. Employment law provides a good example of this. The sources of employment law are very complex, differ among Member States, and have different effects. Overly broad statements not expressly limited to the facts of a case can produce a situation where a well-balanced relationship between employer and employee interests in a given national legal order tilts prejudicially one way or the other. The problem becomes acute when the reasoning fails to address the possibility that national legal regimes may provide alternative protections.

\section{Poor Quality of European Legislation}

What has been discerned about the judiciary applies as well to EU legislation. It is true that during the legislative process, national legal orders are compared in order to establish the reasonable basis for harmonization. Yet no further attempt is made to foresee the effects, which above all would have the secondary consequence of unburdening the ECJ. Moreover, the statutory texts in

\footnotetext{
${ }^{35}$ See Thomas Riehm, Pro und contra Europäisches Fachgericht für Privatrecht, in ZIVILGERICHTSBARKEIT UND EuropÄisches Justizsystem, 204, 205 (Beate Gsell \& Wolfgang Hau eds., 2012).

${ }^{36} \mathrm{See}$ Court of Justice of the European Union Annual Report 2014, at 9, https://curia.europa.eu/jcms/upload/docs/ application/pdf/2015-04/en_ecj_annual_report_2014_pr1.pdf; see also Vassilios Skouris, Höchste Gerichte an ihren Grenzen - Bemerkungen aus der Perspektive des Gerichtshofes der Europäischen Gemeinschaften, in FESTSCHRIFT FÜR Christian STARCK ZUM SiEbZigsten GeburtSTA, 991, 994-95 (R. Grote et al. eds., 2007).

${ }^{37}$ See Jacobs, supra note 17 , at 212.
} 
different languages are all equally binding whereas the possibility of totally accurate translations is subject to the limitations of language itself. This is particularly serious as it is common for the ECJ to engage in plain language statutory interpretation. Ultimately, any reform of the jurisdiction of the EU will not be able to ameliorate these two circumstances.

\section{Different Legal Backgrounds of the Judges}

The Member States' national legal systems may have common roots in Roman law, ${ }^{38}$ but beyond that there is no common legal tradition. Since the beginning of the ECJ, no independent European understanding of law has emerged. Quite the opposite, the working methods and legal traditions of the individual judges bear the imprint of their national legal orders to a large extent and differ from one another significantly. ${ }^{39}$ Despite that for practical reasons cases are decided not by the full ECJ, but rather by panels of three, five or-rarely-fifteen judges, the diversity still necessitates a balancing among traditions of the participating judges. In light of this, former ECJ Judge Ulrich Everling has noted it is surprising that the community of judges were able to adopt a judicial practice that the European legal community, in particular those tasked with applying the law, could ever accept in the first place.

\section{Diversity of Views on the Court and Historical Development}

A main point of criticism we have already identified is the fact that opinions often contain unduly brief reasoning or lack reasoning altogether. This mode of rendering decisions is traceable to two circumstances. For one thing, the ECJ was founded upon the French law of administrative procedure. ${ }^{40}$ It even adopted, and has maintained to this day, the terse French style of judgments. The other thing is that, while judges can often agree on the result, they frequently part ways on the reasons. ${ }^{41}$ To avoid overly time-consuming deliberations, they are thus prone to strike out controversial passages from the reasoning. ${ }^{42}$ This "striking technique" (German Streichtechnik) contributes to the brevity of stated reasons. ${ }^{43}$

\section{The Problem of Languages}

An institution involving judges, Advocates General, référendaires, and staff from twenty-eight Member States needs a common working language. At the ECJ, it is French, which has advantages and disadvantages. A common language contributes to the cohesiveness of the institutions. Moreover, the use of French forces the judges to reflect anew on their positions because they must give explanations in a language not their own and thus in another terminological context.

The disadvantages arise primarily for non-Francophone judges. A judgment written in one's own language will, as a rule, be more precise and, thus, more persuasive. Also, not all terms of art will have a French counterpart. Even for national judges, the problem of languages has

\footnotetext{
${ }^{38}$ See Ulrich Everling, Zur Begründung der Urteile des Gerichtshofs der Europäischen Gemeinschaften, 1994 EUROPARECHT $127,132$.

${ }^{39}$ See Ulrich Everling, Die Zukunft der europäischen Gerichtsbarkeit in einer erweiterten Europäischen Union, 1997 EuROPARECHT 398, 407; see also Robert Rebhahn, Arbeitnehmerschutz à la européenne. Referate im Rahmen der Vortragsreihe "Rechtsfragen der Europäischen Integration," Bonn, den 17. November 2014, 39 (2014); Stefan Leible, Die Rolle der Rechtsprechung des Europäischen Gerichtshofes bei der europäischen Privatrechtsentwicklung, in AUF DEM WEGE ZU EINEM EuropäISCHEN ZivilgeSETZBUCH 53, 78 (D. Martiny \& N. Witzleb eds., 1999). C.f. Woods, supra note 11, at 341, 347.

${ }^{40}$ See Ulrich Everling, Zur Gerichtsbarkeit der Europäischen Union, in EUROPA IM WANDEL. FESTSCHRIFT FÜR HANSWerner Rengeling Zum 70. Geburtstag am 25. Februar 2008, 527, 528 (J. Ipsen \& B. Stüer eds., 2008).

${ }^{41} C f$. Woods, supra note 11, at 345 ("The judgment is an expression of the form of agreement rather than necessarily a record of a logical argument ...").

${ }^{42}$ See Michael Ahlt, Personelle Besetzung des EuGH und "Entscheidungskultur", in ZIVILGERICHTSBARKEIT UND EuropäisChes Justizsystem 35 (B. Gsell \& W. Hau eds., 2012); see also Sharpston, supra note 18, at 766.

${ }^{43}$ Ahlt, supra note 42 , at 35.
} 
far-reaching consequences. The criticism levelled against condensed reasoning of opinions again figures prominently here. If judgments are to be enforced in all Member States, national judges presumably must be able to understand them. Especially if a judgment refers to legal concepts or institutions not formally present, or not present in a given form in some Member State, then where there is no exact translation, the judgment must do more in the way of outlining and explaining those concepts or institutions. ${ }^{44}$

Due to the diversity of languages, judges also cannot take into account any relevant literature written in a language they do not command. The high cost of translation means that more extensive works do not appear in translation, which disadvantages the discourse with legal scholarship, which frequently operates just at the national level.

\section{Universal Responsibilities of ECJ Panels Instead of Specialization}

In many Member States there are specialized tribunals on which expert judges are empaneled for areas of law that are complex or exhibit other special features. ${ }^{45}$ This is the only way to ensure that judgments of sufficient quality issue within a short period of time.

The ECJ has done without this kind of specialization so as not to let the legal tradition of one Member State loom too large in any area of law. Although EU law has come to encompass a multitude of areas of law, every judge is still supposed to decide in every one of them. To this end, judges must perpetually acquaint themselves with one subject matter after another, which the judges themselves feel to be very taxing. Lasting engagement with one area of law yields deeper knowledge of that area and enables judges to dispose of cases in that area more quickly. It not only shortens the proceedings and is cost-efficient, but also the time saved allows judges to engage in more extensive research in their specialized area of law. It thus becomes possible to accumulate a pool of knowledge, even one that can be transmitted to the next generation, when a specialist judge leaves the bench. ${ }^{46}$

The role of the ECJ is interesting in light of this universal responsibility. The qualifications for appointment to the ECJ correspond to those for appointment as a national constitutional court justice. The ECJ is tasked with ruling on a broader range of issues than just those arising under the primary EU law, however, which is comparable in many respects to national constitutional law. Within the confines of the preliminary rulings procedure - the most significant type of proceeding there - the ECJ rules on and interprets secondary law. The judicial activities under the preliminary rulings procedure strongly resemble those of special national tribunals. The ECJ thus fulfils a dual role as both a constitutional and a special jurisdiction court, though the latter activity is much more pronounced.

With secondary law expanding continually, and in light of the fact that the Member States do not all have separate constitutional jurisdictions but instead have instituted specialized tribunals to a greater or lesser extent across their court systems, it is not easy to comprehend why the ECJ should be averse to specialization. One veiled piece of evidence, that continuity of personnel and deepened knowledge in one body of law also holds advantages for the ECJ, appears from the reality of the past two decades, in which we have seen cautious specialization among the Judges-Rapporteur. The President of the ECJ sometimes assigns additional cases, referred in a given area of law, to judges who have already worked on a referral involving a particular directive in the past. Certain duos of a Judge-Rapporteur and an Advocate General have made their marks on lines of cases this way. ${ }^{47}$

\footnotetext{
${ }^{44}$ See Vassilios Skouris, Law and Languages, 2016 BUCERIUS L.J. 5, 8 (providing a similar approach to avoiding linguistic divergences).

${ }^{45}$ See Matthias Jacobs et al., Spezialisierung der Unionsgerichtsbarkeit im Arbeitsrecht - Fachkammer für Arbeitsrecht am EuGH, HIS-SCHRIFTENREIHE Band 17, 22-34 (2016).

${ }^{46}$ See Franklin Dehousse, The Reform of the EU Courts. The Need of a Management Approach, Egmont Paper 53, Dec. 2011, at 18 .

${ }^{47} \mathrm{See}$ Dehousse, supra note 33, at 61 (showing that in approximately $40 \%$ of cases, the Judge-Rapporteur and the Advocate General are appointed based on the criterion "related cases").
} 


\section{Specialization in the Preliminary Rulings Procedure as a Rewarding Pursuit}

The improvements that stand to be achieved through introduction of a specialized preliminary rulings procedure are aimed at garnering greater acceptance of the jurisdiction of the EU in the Member States. Specialization is a way to make judgments easier to understand and litigation results more predictable. ${ }^{48}$

\section{Benefits}

\subsection{Systematic Development in Subject Areas and Legal Certainty for Those Who Apply the Law}

Specialization can help boost systematic development in individual areas of law and consistency among judgments. ${ }^{49}$ The prerequisite for developing a coherent system of law is continuity within the judiciary. ${ }^{50}$

The current Chambers system at the ECJ entails cases arising in substantially similar areas of the law being decided by shifting panels of varying composition. The current design guarantees that one decision after another will be taken on the basis of minimal consensus. ${ }^{51} \mathrm{~A}$ smaller, not constantly, shifting composition would facilitate compromise in the long run and thereby enable systematic development in a given area of law. ${ }^{52}$

Systematic development eventually leads to greater legal certainty and clarity about the law for those who must apply it. ${ }^{53}$ Not until a stable, uniform, jurisprudence has developed will courts in the Member States be able to resolve similarly situated cases themselves without having to rely on assistance from the ECJ as they have done in many instances so far. A coherent systematic development thus contributes to lowering the number of procedures.

\subsection{Specialized Knowledge and More In-Depth Reasoning}

Specialization alone is certainly not capable of altering the traditional form of written opinions. It does, however, contribute to letting the same judges grapple with one area of law over a longer time frame. ${ }^{54}$ Such continuity is a prerequisite to a judge attaining special expertise in an area of law. Knowledge specific to an area of law, accumulated over time, does have the potential to lead to more in-depth reasoning of judgments. ${ }^{55}$ If there were specialized chambers, the composition of which were not constantly shifting, the necessity of striking out passages of an opinion could be expected to diminish. Increased knowledge of a subject matter is also closely related to systematic development. It would allow the judges to communicate their thinking to the public more easily through their written decisions and thereby promote greater acceptance in the Member States.

\footnotetext{
${ }^{48}$ But see Lawrence Baum, Probing the Effects of Judicial Specialization, 58 DuKE L.J. 1667, 1681 (2009) (according to whom empirical evidence of the impact of specialization is limited).

${ }^{49}$ See R. Arnold, Case Management, Judicial Specialisation and Intellectual Property Litigation, 29 CIV. JUST. Q. 478, 485 (2010); see also Rochelle C. Dreyfuss, The Federal Circuit: A Case Study in Specialized Courts, 64 N.Y.U. L. ReV. 1, 6-23 (1989). Cf. Edward K. Cheng, The Myth of the Generalist Judge, 61 STAN. L. REv. 519, 549 (2010).

${ }^{50}$ See generally Clemens Latzel, Vorabentscheidungsverfahren und prozedurale Voraussetzungen richterrechtlicher Systembildung, in DAS VORABENTSCHEIDUNGSVERFAHREN IN DER ZivilgerichtsbarkeIt. 4. ÖsterReichische Assistententagung zUm Zivil- Und Zivilverfahrensrecht der Karl-Franzens-Universität GraZ 93 (von Selena Clavora \& Thomas Garber eds., 2014).

${ }^{51}$ See Juliane Kokott \& Christoph Sobotta, Der EuGH: Blick in eine Werkstatt der Integration, Europaische GrundrechteZeitschrift 465, 472 (2013).

${ }^{52}$ See Rousselot, supra note 3, at 284; see also Latzel, supra note 50, at 93.

${ }^{53}$ See Ulrich Ehricke, Spezialisierung als Rechtsprinzip für die Zuständigkeit im deutschen Zivilverfahrensrecht?, 1996 NEUE JURISTISCHE WOCHENSCHRIFT 812, 816.

${ }^{54}$ See Dehousse, supra note 33, at 53 (also attributing the increase in productivity at the GC in 2014 to the fact that there were no new judges).

${ }^{55}$ See Cheng, supra note 49, at 549; see also Rochelle C. Dreyfuss, Specialized Adjudication, BYU L. REv. 377,378 (1990). Cf. Harold H. Bruff, Specialized Courts in Administrative Law, 43 ADMIN. L. REV. 329, 330 (1991).
} 


\subsection{Better Foreseeability of Effects}

In the long run, judges who hear numerous cases arising in different Member States in one subject area learn not just about special features of national legal orders, but also about special features of the respective domains of life. Thus, specialized judges are better able to understand, from legal as well as factual perspectives, what effects their decisions will produce, and can better foresee the effect of judgments without having to expend additional resources.

\subsection{Shorter Duration of Proceedings and Better Cost Efficiency}

Shorter proceedings and the attendant gain in cost efficiency are momentous arguments in favor of specialization. ${ }^{56}$ Specialized judges with great knowledge of a particular subject are able to handle cases more quickly. ${ }^{57}$ It saves them the long time it takes to get acquainted with unfamiliar subject matter, and thus they need not seek information beforehand about fundamental legislative value judgments or the European and national legal frameworks. ${ }^{58}$

Shorter proceedings incur lower costs per case. Moreover, a coherent systematic development would result in fewer cases reaching the ECJ, which would lessen the case load. Potential cost savings, however, are not to be found at the level of judges themselves because their number is firmly prescribed in Article 19 (2) subparagraph 1 sentence 1 TEU. But potential savings would present themselves at the administrative level as well as with translation services. An added benefit would accrue from shorter proceedings at Member State level, which would in turn feed back into savings there.

\section{Manageable Disadvantages \\ 2.1 Non-Uniform Legal Development and Lack of Attention to Particular Legal Orders}

Introducing specialization into the EU judicial system, of course, risks negatively affecting the coherence of EU law. ${ }^{59}$ On the one hand, different interpretations of EU law could emerge if different courts or chambers adjudicate on similar legal issues in different contexts. It is also true that if some legal traditions no longer participate in continuing legal development in each area of law, then it may result in insufficient consideration of the vantage point from particular national legal regimes. On the other hand, the advantages of enabling judges to establish clear lines of decisions and a uniform jurisprudence are substantial as we have shown. Furthermore, the disadvantage can be made manageable, in part, through the way specialization is set up, and especially through the choice of judges.

\subsection{Problems in Drawing the Boundaries of Jurisdiction}

Every specialization encounters the problem of demarcating jurisdictional boundaries from one specialized panel to the next. Yet jurisdictional conflicts are resolvable. The solution lies in designating an organ to decide, in doubtful or conflicting cases, which court or panel shall take cognizance of a case. The fundamental possibility of drawing such boundaries is already apparent from the fact that many national legal orders maintain special jurisdictions or tribunals for certain subject matter. Here too, problems of delineating competences arise, but these problems are manageable in practice.

\footnotetext{
${ }^{56}$ See Dehousse, supra note 46 , at $\$ \$ 4.1-4.2$.

${ }^{57}$ See Arnold, supra note 49, at 485; see also Bruff, supra note 55, at 331; Dreyfuss, supra note 55, at 378. But see Dreyfuss, supra note 49, at 23-24 (stating that he was unable to detect efficiency gains five years after the creation of a specialized court in the USA, but believing they may need longer to materialize).

${ }^{58}$ E.g., Ehricke, supra note 53, at 816 (regarding German jurisdiction); see also Jurgen Blomeyer, Der Ruf nach dem spezialisierten und sachverständigen Richter, 1970 ZEITSCHRIFT FÜR RECHTSPOLITIK 153.

${ }^{59}$ See Woods, supra note 11 , at 348 . Cf. Cheng, supra note 49 , at 552-53.
} 


\section{Models of Reform Toward Specialization of European Union Jurisdiction}

Whoever is satisfied that specialized EU jurisdiction will procure greater acceptance of its jurisprudence has to examine possible models for reform. Around the turn of the millennium there was discussion, in particular, of the possibility of setting up decentralized EU courts in all or some of the Member States. ${ }^{60}$

Decentralization was viewed as a way to achieve greater proximity, by subject matter, between EU courts and the Member States, for example, a specialization in one or more individual Member States. Yet, this idea of decentralized EU courts was never agreed upon in the process of amending the European treaties. This Article looks at three models of reform for which there is room within the scope of the TFEU.

\section{Specialized Court}

Article 257 TFEU enables the European Parliament and the Council to set up specialized courts attached to the GC. The only such court set up so far has been the Civil Service Tribunal, which was integrated into the GC as of September 1, 2016, as we noted earlier. Specialized courts may be authorized to hear certain classes of action or proceedings brought in specific areas at first instance, per Article 257 (1) sentence 1 TFEU. An appeal, limited to points of law, may be lodged before the GC against decisions of the specialized courts. That is unless, in setting up the specialized court, the scope of appeal is expanded to include points of fact, Arts. 257 (3), 256 (2) subparagraph $1 \mathrm{TFEU}$. If the GC has rendered a decision, the ultimate possibility is to petition for review by the ECJ, Article 256 (2) subparagraph 2 TFEU. This last appeal, however, is limited to cases which pose a serious risk of affecting the unity or consistency of EU law.

\section{Specialized Chambers at the General Court}

The GC forms Chambers to render decisions. Pursuant to Article 25 of the Rules of Procedure of the General Court ("RPGC"), the GC shall lay down criteria by which cases are sent to Chambers. Article 25 (1) sentence 2 of the RPGC expressly provides that specialized chambers can be set up: "The General Court may make one or more Chambers responsible for hearing and determining cases in specific matters." After having previously assigned cases solely in the order in which they are entered at the Registry, ${ }^{61}$ the plenum recently laid down new criteria. These criteria provide for civil service cases and cases concerning intellectual property to be heard by specialized chambers. ${ }^{62}$ Specialization has, therefore, now been introduced at the level of the GC in two areas of law.

Presently, the GC has jurisdiction to hear only the types of actions or proceedings explicitly mentioned in Article 256 (1) TFEU. Article 256 (3) TFEU provides, however, the possibility that "in specific areas laid down by the Statute" the GC may be assigned jurisdiction to hear preliminary ruling procedures. ${ }^{63}$ Therefore, to declare that the GC has jurisdiction to hear preliminary ruling procedures, at least in certain areas of law, would require an amendment to the Statute of the Court of Justice of the European Union ("Statute of the CJEU"). Article 281 (2) TFEU provides a detailed procedure for amending that statute. The ECJ and the Commission are empowered to initiate such legislation.

\footnotetext{
${ }^{60}$ See Court of Justice of the European Union, The Future of the Judicial System of the European Union: (Proposals and Reflections) ('The Courts' Paper), in The Future of THE Judicial System of the European Union 139-40 (Alan Dashwood \& Angus Johnston eds., 2001); see also J. P. Jacqué \& J. H. Weiler, On the Road to European Union - A New Judicial Architecture: An Agenda for the Intergovernmental Conference, 27 CoMmON MKT. L. REv. 185, 192-95 (1990).

${ }^{61}$ See generally 2016 O.J. (C 296/02), https:/eur-lex.europa.eu/legal-content/EN/TXT/PDF/?uri=CELEX:C2016/296/ $04 \&$ from $=$ DE.

${ }^{62} 2019$ O.J. (C 246/02), https://eur-lex.europa.eu/legal-content/EN/TXT/PDF/?uri=OJ:C:2019:246:FULL\&from=DE.

${ }^{63}$ J. H. Weiler, Editorial: A Faustian Bargain?, 14 INT'L J. ConsT. L. 321, 323 (2016); see also Alemanno, supra note 2, at 174-75 (advocating the granting of GC jurisdiction over preliminary ruling procedures).
} 


\section{Specialized Chambers at the ECJ}

Like the GC, the ECJ forms Chambers to hear cases and render decisions. In addition to Chambers of three and five judges there is - acting as panels - the Grand Chamber of 15 judges, as well as the full Court. Yet, unlike the General Court, the ECJ does not have a formal process by which cases are assigned to Chambers. Pursuant to Article 15 of the Statute of the CJEU, if a case reaches the ECJ, the President first designates a Judge-Rapporteur, who draws up a preliminary report for presentation to the general meeting of the Court. The preliminary report contains inter alia a proposal for which panel ("formation") is to be tasked with hearing the case, Article 59 (2) sentence 1 Statute of the CJEU. The general meeting of the Court, which is composed of all the ECJ's judges and Advocates-General, then decides which Chamber to charge with hearing the case, cf. Article 25 sentence 1 Statute of the CJEU. Typically, the Judge-Rapporteur is a member of this Chamber. By virtue of the fact that the President alone designates the Judge-Rapporteur, he or she has overriding influence over the eventual assignment to a panel. In choosing the JudgeRapporteur, the President takes into consideration such factors as current work load and prior experience of the judges in the particular area of law, as well as their nationality. ${ }^{64}$

If one were to set up special chambers at the ECJ, there are two ways to go about it: Either through purely discretionary actions by the President or in a legally binding fashion. The President could simply designate judges from a given Chamber as Judges-Rapporteur for a particular legal subject matter. Because in the vast majority of instances the general meeting assigns cases to the Chamber to which the Judge-Rapporteur belongs, the practical result would be a specialized chamber. This specialized chamber would be a non-binding establishment. Case assignments are for the President's own discretion, and the President is not bound to bring about specialization. By contrast, if a specialized chamber is meant to be a mandatory establishment, two steps must be taken. One, a particular Chamber must be designated as the specialized chamber, and two, it must be ensured that the President names one of the judges on that Chamber as Judge-Rapporteur. In other words, the mandatory version necessitates directing the President's discretion.

\section{Specialized Chambers at the ECJ as a Logical Step in the Development of the Jurisdiction of the European Union}

Now that the three possible models have been sketched out, what remains is to evaluate them. What are the advantages and disadvantages of each? In doing so, it is important to maintain focus on the central role of preliminary ruling procedures in ensuring coherence of EU law. Further factors to be considered include the political will to institute reform or whether reform might prolong some proceedings.

\section{Special Jurisdiction in Preliminary Ruling Procedures Requires Amendment to the TFEU}

If specialized courts were to be instituted for certain areas of law, it would go a long way toward achieving specialization with numerous attendant advantages. ${ }^{65}$ Nevertheless, because this Article addresses specialization of the jurisdiction of the EU in preliminary ruling procedures, due regard must be paid to whether specialized courts lex lata are even permitted to hear such procedures in the first place.

\footnotetext{
${ }^{64}$ See Bernhard W. Wegener, Art. 251 TFEU, in EUV/AEUV. KOMMENTAR 5 (C. Calliess \& M. Ruffert eds., 5th ed. 2016); see also Ulrich Karpenstein, Art. 251 TFEU, in DAS RECHT DER EUROPÄISCHEN UnION 18 (E. Grabitz et al. eds., 60th ed. 2016); Woods, supra note 11, at 344 .

${ }^{65}$ See Rousselot, supra note 3, at 284 (emphasizing cost and time savings and suggesting proposals to compensate disadvantages); see also Dehousse, supra note 46 , at $\$ 4$; Dehousse, supra note 18 , at $\$ 5.3$ (arguing in favor of establishing specialized courts).
} 
Under Article 257 (1) TFEU, specialized courts may be established to hear "certain classes of action or proceeding." Even though "proceeding" is a broad term, it does not cover the preliminary rulings procedure. ${ }^{66}$ This is apparent from systematic comparison with Article 256 TFEU, which concerns regulations of the GC, namely in paragraphs 1 and 2 as they pertain to its jurisdiction. Paragraph 3 was created specifically to deal with the preliminary rulings procedure. It lays down rules that differ from those applicable to other types of proceedings the GC has jurisdiction to hear and establishes a right to refer cases to the ECJ. Moreover, Article 256 paragraph 3 TFEU contains a stricter barrier to appeals. By contrast, Article 257 TFEU does not differentiate among types of proceedings. It is difficult to imagine that the Member States, as framers of the Treaties, would have intended to regulate the preliminary rulings procedure before the GC separately, but not make such a procedure subject to special rules before a specialized court. More likely, the comparison between Articles 256 and 257 TFEU indicates that the Member States considered, but rejected, the idea of empowering specialized courts for the preliminary rulings procedure.

Supposing even that the TFEU were to be amended, which is hardly imaginable given the state of politics at present, ${ }^{67}$ it is not advisable to make use of specialized courts to effectuate specialization in preliminary ruling procedures. Specialized courts, unlike specialized chambers set up within the ECJ or the GC, offer less flexibility. ${ }^{68}$ The judges assigned to a specialized court would be unavailable to take on other duties if there were a lighter case load at some time. Moreover, the duration from beginning to end of a litigation could increase significantly if a preliminary ruling procedure had to run its course through as many as three European instances before the legal dispute at the national level could be resolved. ${ }^{69}$

\section{Risks to Coherent European Union Jurisprudence Posed by Specialized Chambers at the General Court with Jurisdiction to Hear Preliminary Rulings Procedures}

Bringing specialization to the EU's jurisdiction to hear preliminary ruling procedures by transferring that jurisdiction in certain areas to the GC and setting up specialized chambers there is a solution that brings together all the advantages of specialization. First, specialization at the GC with jurisdiction to hear preliminary ruling procedures is advantageous because it is easier for the GC to react to increasing caseloads. ${ }^{70}$ The number of judges sitting on the GC is provided in the Statute of the CJEU, Article 254 (1) TFEU. Yet the number of judges at the ECJ is governed by Article 19 (2) subparagraph 1 sentence 1 TEU. If caseloads were to rise, theoretically at least, it would be easier to appoint additional judges to the GC than to the ECJ, as it would require only an amendment to the Statute of the CJEU rather than the TEU. Practically speaking, however, the gain in flexibility is smaller than it might seem, as revealed by the debate surrounding expansion of the GC and elimination of the Civil Service Tribunal. For years it was impossible to fill open judgeships on the Civil Service Tribunal, nor was there agreement on how many new judgeships to create at the GC. ${ }^{71}$ In the end, the number of judges at the GC was doubled and the Civil Service Tribunal eliminated in what was seen as the only way to assuage the fears of some

\footnotetext{
${ }^{66}$ Riehm, supra note 35, at 217; see also Latzel, supra note 50, at 94 . For a different view, see J. Basedow, Die rechtsstaatliche Dimension der europäischen Justizreform, 66 RABELS ZEITSCHRIFT FÜR AUSLÄNDISCHES UND INTERNATIONALS PRIVATRECHT 203-04 (2002).

${ }^{67}$ See Riehm, supra note 35, at 223 (sharing this assessment).

${ }^{68}$ See Draft Amendments to the Statute of the Court of Justice of the European Union and to Annex I Thereto (Mar. 28, 2011) 8.

${ }^{69}$ See Riehm, supra note 35, at 222-23.

${ }^{70}$ See CJEU, supra note 60, at 131-32; see also Hakenberg, supra note 33, at 864.

${ }^{71}$ See Vassilios Skouris, Response of the Court of Justice to the Presidency's Invitation to Present New Proposals on the Procedures for Increasing the Number of Judges at the General Court of the European Union, Interinstitutional File: 2011/0901B (COD) 2-3 (Nov. 20, 2014).
} 
Member States that they stood to lose influence over EU jurisprudence if some could send only one while others sent two judges to the GC. But if the only choice is either to increase the number of judges by the number of Member States or do nothing, the gain in flexibility is greatly relativized.

Those considerations aside, it is hard to imagine the ECJ relinquishing its jurisdiction to hear preliminary ruling procedures and limiting itself purely to serving as an appeals court for this type of procedure. ${ }^{72}$ Another good argument why preliminary ruling procedures should not be placed in the hands of specialized chambers at the GC is the coherence of EU law. ${ }^{73}$ One of the most important tasks of the ECJ is to uphold the coherence of EU law. ${ }^{74}$ Yet, an appeal from the GC to the ECJ lies subject to strict conditions only. ${ }^{75}$ Article 256 (3) subparagraph 3 TFEU provides there must be "serious risk of the unity or consistency of Union law being affected." Thus, in a case of non-serious risk, the matter does not reach the ECJ and consequently, preliminary ruling procedures are subject to final judgment at two different levels. If one were to reach the ECJ, it furthermore would prolong litigation despite Article 62(a) of the Statute of the CJEU's requirement that the ECJ review the application urgently. ${ }^{76}$

\section{Specialized Chambers at the ECJ as the Best Solution}

Setting up specialized chambers at the ECJ further develops the jurisdiction of the EU, but does so carefully. ${ }^{77}$ This solution leaves intact both the pre-existing Chambers system as well as the distribution of jurisdiction between the ECJ and the GC. The changes it entails are courtinternal only. To be sure, specialized chambers would operate to constrain the President somewhat in assigning cases to Judges-Rapporteur whereas the President's flexibility in this area has been cited as one of the things that made shorter litigation times possible. If specialized jurisdictions are distributed sensibly among the Chambers, it should be possible to avoid placing an undue burden on just one Chamber. Furthermore, it is important to acknowledge that one can opt to specialize Chambers only partially, rather than conferring a single specialized jurisdiction on any one of them. Parallel to the special competence, each Chamber could thus retain a general jurisdiction under which it could be designated to hear cases that lie outside its subject matter focus.

Opponents of specialization at the ECJ maintain that thereafter some national legal regimes would drop out of legal finding in a given subject area. ${ }^{78}$ This possibility cannot be ignored. To counter it, attention must be payed to making sure that judges who form a Chamber hail from different legal systems. To this end, the ECJ ought to group Member States together whose modes of legal thought or value systems are similar. ${ }^{79}$ Moreover, one must consider that at present, the

\footnotetext{
${ }^{72}$ See Council of THE Eur. Union, supra note 5, at 6 (illustrating this point as evidenced by the Court of Justice's report).

${ }^{73}$ See Council of the Eur. Union, supra note 5, at 6. Cf. Ulrich Karpenstein, Art. 256 TFEU, in DAS RECHT DER EURopÄISCHEN Union 67 (E. Grabitz et al. eds., 60th ed. 2016). For a different view, see Ulrich Everling, Stand und Zukunftsperspektiven der Europäischen Gerichtsbarkeit, in FESTSCHRIFT FÜR ARVED DERINGER 51 (U. Everling et al. eds., 1st ed. 1993).

${ }^{74}$ See Council Decision, 1988 O.J. (L 319) 1; see also CJEU, supra note 58, at 120; Court of Justice of the European Union. Commentary on Statute and Rules of Procedure, intro. para. 7 (Bertrand Waegenbaur ed. 2013).

${ }^{75}$ See Council of The Eur. Union, supra note 5, at 8 (with the Court of Justice stressing this point).

${ }^{76} \mathrm{See}$ CounCIL OF THE EUR. UNION, supra note 5, at 7. Cf. Skouris, supra note 36, at 1000 (calling for close examination of the effect on overall duration of the proceedings of assigning to the GC jurisdiction to hear preliminary rulings procedures).

${ }^{77}$ See S. Prechal, The Many Formations of the Court of Justice: 15 Years After Nice, 39 FordHAM INT'L L.J. 1272, 1286-87 (2016) (opposing specialization of chambers at the ECJ).

${ }^{78}$ See Everling, supra note 72, at 45. Cf. K. J. Hopt, Reform der europäischen Gerichtsbarkeit: Überlegungen zur aktuellen Reformdiskussion, 66 Rabels ZeITSCHRIFT FUR AUSLANDISCHES UND INTERNATIONALS PRIVATRECHT 589, 599 (2002) (believing this to be not harmful).

${ }^{79}$ See Hopt, supra note 77, at 596 (on the representation of interacting groups or bodies of law on two panels at the ECJ). But see Everling, supra note 39, at 407 (arguing that the legal regimes are so divergent that they are not easily amenable to grouping).
} 
majority of decisions are taken by Chambers of three and five judges. ${ }^{80}$ It transpires that all legal regimes figure into deliberations only if the ECJ has convened the Full Court, an absolutely exceptional occurrence. The influence of all legal regimes in a given area of law-in the sense that none are ignored-is already slight as it stands. The only channel for an influence of all Member State regimes is through cases in a particular area of law being heard and decided from time to time by different Chambers. But the same set-up ensures that no judgments come down that contribute to systematic development, because each Chamber will be anxious to not bind other chambers by setting out fundamental principles that apply beyond the case at hand. ${ }^{81}$

There is a concern that assigning some legal matters to specialized Chambers will produce incoherent development of EU law. Lines of decisions among special chambers could diverge from one Chamber to the next. This risk, however, is manageable. Even today the General Meeting assigns cases to the Grand Chamber when there seems to be a problem of coherence. ${ }^{82}$ Also, the Grand Chamber is mandatorily called upon to preside whenever a Member State or EU institution party to the proceedings so requests, Article 16 (3) Statute of the CJEU. The Member States and institutions of the EU can also exercise this right when they regard a proceeding as essentially important to the coherence of EU law. Furthermore, a Chamber seized of a given procedure ought to be placed under a duty to refer it to the Grand Chamber whenever the presiding Chamber intends to deviate from the jurisprudence of another Chamber. It would have to be ensured, via amendment to Article 27 (1) of the ECJ Rules of Procedure (RPECJ) that at least one member of the specialized Chamber sits on the Grand Chamber in such event. The risk to coherence from instituting specialized Chambers thus is small and manageable.

While the disadvantages of specialized Chambers at the ECJ are not serious, this arrangement would carry with it all the previously mentioned advantages of specialization. Besides, this model of reform does not represent a radical departure from the existing architecture of the court-it is evolution rather than revolution. It is also relatively simple to realize politically, and is costeffective. It only necessitates amendments to the Statute of the CJEU and RPECJ. It does not require that a new court unit be created. On a per-procedure basis, it will even lead to cost savings because specialized judges will need less time to handle cases.

\section{Setting Up a Special Chamber at the ECJ}

Because specialized Chambers at the ECJ represent the most compelling way to achieve specialization in the jurisdiction of the EU, the following sections examine how such a Chamber may be arranged.

\section{Establishing Special Chambers on a Mandatory Basis}

As previously mentioned, a special Chamber might be set up on a mandatory or permissive basis. A mandatory establishment requires an amendment to the RPECJ. Article 11 (2) of the Rules already contains a regulation conferring special responsibilities upon Chambers, namely for the urgent preliminary ruling procedure and for appeals lodged by the First Advocate General to uphold the unity or coherence of EU law against decisions of the GC. One can pick up where this specialization leaves off and insert a new, brief paragraph 2a: "The Court shall designate the jurisdictions of the chambers of three and five judges by fields of law." Moreover, paragraph 5 requires additional language: "The composition of the Chambers, the designation of the

\footnotetext{
${ }^{80}$ See generally Court of Justice of the European Union Annual Report 2016-Judicial Activity. In 2016, only 8.4 \% of cases were heard by the Grand Chamber and none by the Full Court.

${ }^{81}$ See generally Constantin Baron van Lijnden, Ein (fast) unerreichbares Amt- Interview mit Thomas von Danwitz, LEGAL TRIBUne OnLINE (Nov. 25, 2013), https:/www.lto.de/recht/job-karriere/j/richter-eugh-thomas-von-danwitz-auswahlverfahren/. Thomas von Danwitz, the German judge of the ECJ, has called this a "philosophy of small steps."

${ }^{82}$ See Prechal, supra note 82 , at $1280-81$.
} 
Chambers responsible for cases of the kind referred to in Article 107 and Articles 193 and 194 and the jurisdictions of the Chambers provided for in paragraph 2a shall be published in the Official Journal of the European Union." In order to steer the President's choice of the Judge-Rapporteur, the ECJ must supplement, with the Council's approval, Article 15 (1) of the RPECJ to read: "The President shall select the Judge-Rapporteur of the Chamber the Court has designated under Article 11 (2a) with jurisdiction to rule in the field of law mainly affecting the case."

The other option is to set up specialized Chambers solely on the basis of court-internal guidelines and, thus, in a non-binding way. As opposed to instituting specialized Chambers on a mandatory basis, this would be the lesser solution, though politically it might be easier to enact. The court-internal guidelines would state which types of cases the President ought to assign to judges of which Chamber as Judges-Rapporteur. To imbue the guidelines with a certain binding quality, despite their status as soft law, they should be published on the homepage of the Court of Justice of the European Union. On one hand, this solution offers the benefit that the Council need not be involved because it does not require an amendment to the RPECJ. Furthermore, the President would retain a high degree of flexibility in selecting Judges-Rapporteur. On the other hand, it poses a long-term risk to systematic development if court-internal guidelines might be eliminated with little ado. Because the advantages of specialization accumulate over time, a long-term solution should be pursued that is not susceptible to possible modification on short notice. Such is guaranteed if the specialized Chamber is instituted by way of a modification to the RPECJ.

\section{Partial Specialization}

A specialized Chamber should not exercise one special jurisdiction exclusively, but rather should be just partially specialized. Parallel to their jurisdiction to hear cases in one or several limited areas of law, they retain general jurisdiction under which procedures from all other areas of law can be referred to a Chamber. There are two advantages to this: It limits the feared loss of flexibility in the event of specialization, and lets varying case-loads among Chambers be evened out by virtue of the option to designate more, or fewer, procedures to any one of them under the general jurisdiction. ${ }^{83}$ There will also be less resistance to such a solution from among the ranks of judges because they will continue to hear cases dealing with many areas of law, which is part of the allure of working at the ECJ. As the ECJ itself must amend its procedural rules, it is important that the judges are open to specialization. Any reform should therefore avoid affecting the work of the judges in a way they perceive as negative.

\section{Specialization Limited to a Few Areas of Law}

The reverse implication of instituting only partial specialization among Chambers is that there will necessarily be areas of law that come under the general jurisdiction by default. Not every area of law over which the ECJ presides ought to be designated to a specialized Chamber. The study underlying this Article argues for specialization at the ECJ in the area of employment law. ${ }^{84}$ Adjudication in the area of employment law is challenging. Alongside the individual's interests are collective concerns requiring due consideration, namely the interests of trade associations and labor unions as well as of employees' representatives, be it at particular workplaces or enterprise wide. Collective bargaining agreements and work agreements draw on sources of law unheard of in other areas of law. ${ }^{85}$ Furthermore, employment law systems vary significantly among the

\footnotetext{
${ }^{83}$ See Rousselot, supra note 3, at 284 (pointing out the advantage of broader specialization).

${ }^{84}$ See Jacobs, supra note 45, at 30-45 (outlining the ECJ's difficulties with cases in the area of employment law).

${ }^{85}$ See Marie-Ange Moreau, Is the European Court of Justice Moving Towards Specialization in the Social Field?, in SocIAL Developments in the European Union 2008 Tenth Annual Report 183, 185 (C. Degryse ed., 2009) (seeing "a certain 'particularism"" in the "legal structure relating to labour relations").
} 
Member States. They are grown up over the course of many decades and reflect a balance crafted by judiciary and legislature in the name of avoiding social unrest.

Specialization should not be limited to employment law. A specialized Chamber makes sense whenever deciding cases in one area of law requires relatively elaborate prior understanding of the factual or legal bases. In the last few years, specialization has been discussed, for example, for competition law, intellectual property law, and for trademark law. ${ }^{86}$

\section{Choosing Judges for Specialized Chambers}

When judges demonstrate expertise in an area of law for which a specialized Chamber has been created, they should as a matter of priority be assigned to that specialized Chamber. So far the RPECJ merely state in Article 11 (1) that the ECJ shall decide which judges are assigned to the three and five judge Chambers. The following should be added to this regulation: "When deciding which Judges shall be attached to Chambers responsible for certain areas of law, the Court shall consider the previous experience of the Judges."

Successful specialization, however, does not create a prerequisite for judges to have prior expertise in an area of law that the Chamber they are about to join is set up to handle. The advantages of specialization materialize just as well where a highly qualified judge grapples with the material intensively for an extended period of time. ${ }^{87}$

\section{E. Additional Proposals for Reform}

\section{Specialization of Advocates General}

Alternatively, or in addition to specialization of the judges, a specialization of the Advocates General should be considered. Pursuant to Article 16 (1) RPECJ, the First Advocate General is responsible for assigning cases. The practice is for assignments to rotate according to the order in which cases are registered, while at the same time no Advocate General is assigned to matters lodged from his or her country of origin so as to avoid conflicts of interest. Although firm criteria by which to assign cases are missing, specialization is a minor factor. As with the judges, such specialization can be done in a mandatory fashion by amending the RPECJ or by way of soft law.

\section{Additional Référendaire Positions}

Irrespective of specialization of judges or Advocates-General, it would be possible to employ specialist référendaires. "The creation or appointment of specialist conseillers référendaires would undoubtedly facilitate judicial understanding of many thorny issues linked to specific national contexts." 88 The French government has made a proposal along these lines: The corps of référendaires ought to be increased by an additional group of référendaires of different nationalities who would not be allocated to one judge. They would serve as a platform for exchange and as a resource to field questions of national law; and if need be, they could also tend to the training of the other référendaires.

\section{Involvement of Industry and Labor}

Involving qualified third parties can import another facet into the procedures, namely the insight of practical dealings. The idea here of letting interest groups intervene in international litigation is

\footnotetext{
${ }^{86}$ See Skouris, supra note 70, at 6 (considering a specialized court for intellectual property); see also Everling, supra note 33, at 17 (considering specialized chambers in several areas of law).

${ }^{87} \mathrm{Cf}$. Arnold, supra note 49 , at 483 .

${ }^{88}$ Moreau, supra note 84 , at 198.
} 
not new. Both the ECHR as well as the Rules of Court of the ECtHR provide for third party intervention in case of individual applications, inter alia by industry and labor associations, cf. Article 36 (2) ECHR and Article 44 of the ECtHR Rules of Court. The right of third parties to intervene may be a very wise, low-cost way for judges to obtain additional information characterized by ground-level awareness of the subject matter. Procedures in employment law are particularly suited to invite participation by management and labor as representatives of both sides.

The role of interest groups is not to bolster the litigants' positions in the underlying case, but instead to inject specific experience and insight into the procedure itself. Reservations against this manner of participation by third parties, on the basis that interest groups would exclusively pursue their own legal policy aims, are not persuasive as interest group representation would transpire openly via an institutionalized platform.

In order not to let participation by interest groups lead to longer litigation, the process should be integrated into the existing information and participation system under Article 23 Statute of the CJEU. The added expenditure would consist perhaps in providing notice to management and labor about pending cases in employment law. This would not require a disproportionate effort, provided that the obligation to inform is limited to leading EU level representative associations.

To avoid placing an undue burden on the ECJ, further precautions may be borrowed from the third party intervention process before the ECtHR. One such precaution is to provide, where an intervener petitions for leave to submit written comments, that the petition be duly reasoned with respect to why written comments are called for. ${ }^{89}$ This is a way to ensure third party participation is limited to decisions that affect fundamental principles and does not crop up in every particular case. The ECtHR's practice of curtailing the length and content of written comments makes sense as a way of shielding the judges from an unmanageable quantity of submissions while enabling them to obtain information in a targeted fashion.

\section{F. Five Concluding Theses on Specialization in the Preliminary Ruling Procedure}

1. Specialization can increase the level of acceptance of ECJ jurisdiction in preliminary ruling procedures because it works to ameliorate the basis for criticism of the ECJ's decisions.

2. Specialization can help produce greater legal certainty, more in-depth reasoning of judgments, shorter procedures and improved cost-efficiency.

3. The ECJ should be furnished with mandatory, partially specialized special jurisdiction Chambers. The allocation of jurisdiction between the ECJ and the GC in the area of preliminary ruling procedures should be maintained.

4. Specialization need not be limited to the panels themselves but rather can also take place at the level of the Advocates General or by creating additional référendaire positions.

5. A right of intervention for interest groups has the potential to sharpen the ECJ's ability to foresee the consequences of its judgments.

${ }^{89} \mathrm{Cf}$. Eur. Ct. H.R. Rules of Court art. 44 .

Cite this article: Jacobs M, Münder M, and Richter B (2019). Subject Matter Specialization of European Union Jurisdiction in the Preliminary Rulings Procedure. German Law Journal 20, 1214-1231. https://doi.org/10.1017/glj.2019.85 